\title{
Learning Strategies in English Skills used by Good Language Learners in Millennial Era: A Positive Case Study in Universitas Negeri Makassar
}

\author{
Haryanto Atmowardoyo \\ haryanto@unm.ac.id \\ Universitas Negeri Makassar \\ Sukardi Weda \\ sukardi.weda@unm.ac.id \\ Universitas Negeri Makassar \\ Geminastiti Sakkir \\ geminastitisakkir@unm.ac.id \\ Universitas Negeri Makassar
}

\begin{abstract}
This article is another part of the research results conducted with the aim of developing a theory of learning English as a foreign language. The other part has been reported in the article entitled Information Technology Used by Good Language Learners in Millennial Era in Solid State Technology Vol 3 Issue 5. Theory development is carried out by utilizing best practice as a data source. The research question is "What English learning strategies are used by high achievers in the millennial era?". The main questions are translated into 4 (four) questions based on 4 types of language skills: Listening, Speaking, Reading, and Writing. Research subjects were selected based on academic achievement. Subjects were students of the 4th semester of English Department with 20\% of the best academic achievement. The selected subjects were 40 students from the English Education Study Program and the English Literature Study Program. They were called as good language learners in Universitas Negeri Makassar. The instrument used to collect data was a list of open questions consisting of 12 questions. The list of questions was distributed from March to May 2020 via google form to the WhatsApp account number of the research subjects. The collected verbal data were analyzed by using coding. The results of the study contain descriptions of the types of strategies used by research subjects in improving English listening, speaking, reading, and writing skills. This description also includes the length of time used to improve the four types of English skills. The result shows that, (1) the millennial good language learners use a number of language learning strategies to improve their four types of language skills: listening, speaking, reading, and writing. This information is beneficial for ELT teachers, learners, and further researchers for formulating post pandemic language pedagogy.
\end{abstract}

Keywords: good language learner; language learning strategy; positive case study; English skill; millennial era. 


\section{INTRODUCTION}

Studies of good language learners have been developed since 1975. An epistemological reason for studying the phenomena good language learners is that best practice can be generated a good theory. An article entitled "What can we learn from the good language learners?" written by Rubin (1975) has inspired many researchers to conduct studies about good language learners.

Joan Rubin (1981) herself has conducted at least two studies on successful foreign language learners. The first research aims to explore the characteristics of successful learners; while the second research tries to investigate more deeply about the learning strategies that affect the success of foreign language learning. Then, in the second study, she was able to identify learning strategies that have a direct effect and learning strategies that have an indirect effect. Direct effects include guessing and thinking inductively, while the indirect effect is creating opportunities for practice.

Stern (1983) conducted research on the characteristics of successful foreign language learning. The methods he uses are observation and use of intuition. As a result, Stern presents a list of learner characteristics that are thought to influence foreign language learning success. One of the main points contained in the list of characteristics is a positive learning strategy which includes: (a) active planning; (b) formal learning; (c) social learning; and (d) affective strategies.

Naiman et al (1978) conducted a research study to further explore the characteristics of successful foreign language learners. They used the interview method which was divided into two types: interviews about curriculum vitae and discussions about the strategies used by participants in various learning situations.

Reiss (1985) conducted a study to validate Rubin's findings. He examined the characteristics of successful language learners using the self-report survey method and found findings that were almost the same as Rubin's findings. However, he also found one characteristic item that contradicts Rubin's findings. This characteristic is that learners often feel inhibited from speaking for fear of making mistakes.

Another recent research work on successful foreign language learners is the work of Stevick (1989). With the aim of making a book that contains descriptions of the types of successful foreign language learners, he interviewed seven foreign language learners as research subjects. The data used is in the form of interviews about the learning experiences of these subjects.

From Indonesia, several researchers have also conducted research on good language learners. Sadtono (1986) conducted an investigation into the English language learning process that occurred in three English lecturers who were attending the postgraduate program at IKIP Malang. Two of these subjects are good language learners who can be categorized as successful (good language learners). This successful investigation of the subject reveals a different story. Haryanto (1998) conducted a case study with a single good language learner in senior high school. He finds out that motivation and language learning strategy are those factors affecting the subject's success in learning English as a foreign language. Finally, Griffith et al (2008) issued a book containing 23 articles about good language learners.

We note that this theory was developed from 1975 to 1990, when the digital era had not developed as it is now. Entering the 2000s, the development of information technology (IT) media grew rapidly with the discovery of smart phones that had many functions. The era of the 2000s is known as the millennial era. Regarding the rapid changes from the millennial era, it is necessary 
to study the latest phenomena to develop theories that can be adapted by the millennial generation. Therefore, this research needs to be carried out with a focus as follows: "What learning strategies are used by good language learners in improving their English-speaking skills? What are learning strategies that used by students in improving their English skills?

\section{Language Learning Strategy}

Focusing on the language learning strategies, we review some references related to language learning strategy. The first is Krashen (1982). Professor Stephen Krashen introduces five hypotheses about language learning strategy. One hypothesis mentions that there are two kinds of language learning strategy. The first is conscious learning or formal learning. Conscious learning refers to the way the language learners in improving language skills by focusing on the language forms. Another strategy is popular as the subconscious learning or language acquisition. Subconscious learning refers the way language learners in improving language skills by communication practice with authentic media. This is identical with the way human learn the first language. Krashen emphasizes that subconscious is more important than conscious learning.

The second is Malik and Asnur (2019). They conducted a study entitled Using Social Media as a Learning Media of Foreign Language Students in Higher Education and find out that the YouTube and Instagram are the most popular media used as the media of foreign language students in higher education.

The third is Sakkir (2016). She claims that Learning strategies carried out by good millennial students in improving their language skills currently use electronic media or e-learning media. They take advantage of technological developments that exist today. E-learning can provide motivation and encourage students to learn language skills, listening, speaking, reading and writing English skills.

\section{METHOD}

In order to answer the research questions, a descriptive research design was used. A descriptive research is designed to describe the existing phenomena. This descriptive research can be called by several names, depending on where the research is viewed. From the point of view of the nature under investigation, this research can be more specifically referred to as positive case study research. This is because through this research an in-depth investigation is carried out on a selected case. This designation is in line with Bogdan and Biklen's words which state: "A case study is a detailed examination on one setting, or one single subject, or one single depository documents, or one particular event." And Atmowardoyo (2018) divides case studies into three types: positive case studies, neutral case studies, and negative case studies. A positive case study is the one using a positive case as the phenomena under observation. The epistemological basis for a positive case study is that "a good theory can be generated from the best practice". The studies of good English language learners, effective EFL teachers, and effective EFL program management are those of positive case study. By referring to this definition, it is clear that research which attempts to investigate in depth successful cases of foreign language learning can be categorized as a type of positive case study research.

We planned to observe the subjects selected based on the top 20\% academic achievers in English Department of Universitas Negeri Makassar. The selected subjects include 40 second year students, but due to COVID 19 pandemic, observation could not be conducted. Instead of 
observation, we collected the data using open-ended questionnaires in Google form shared in WhatsApp group of the selected subjects. The data collection was conducted from March until June 2020. The data obtained from the questionnaires were analyzed by coding. Coding technique was used to identify the information technology media used by the research respondents.

The data obtained were analyzed by what Strauss and Corbin (1995) called "coding". This coding is done in the following steps: First, identifying the leaning strategies to improve English Listening, Speaking, Reading, and Writing skills. Second, conceptual labeling the identified learning strategies; third, classifying the types learning strategies according to conceptual labels; forth, calculating the types learning strategies used by the subjects in improving the four types of language skills; and the fifth, describing the types of language learning strategies used by the subjects in the form of a histogram.

\section{FINDINGS AND DISCUSSIONS}

\section{A. Learning strategies used by good language learners in improving their English listening skills}

\section{Types of Strategies in Improving Listening Skill}

Based on the results of data collection and analysis that has been carried out on good language learners in several different classes and different study programs, it was found that several strategies were used by them in improving their skills in English listening skills.

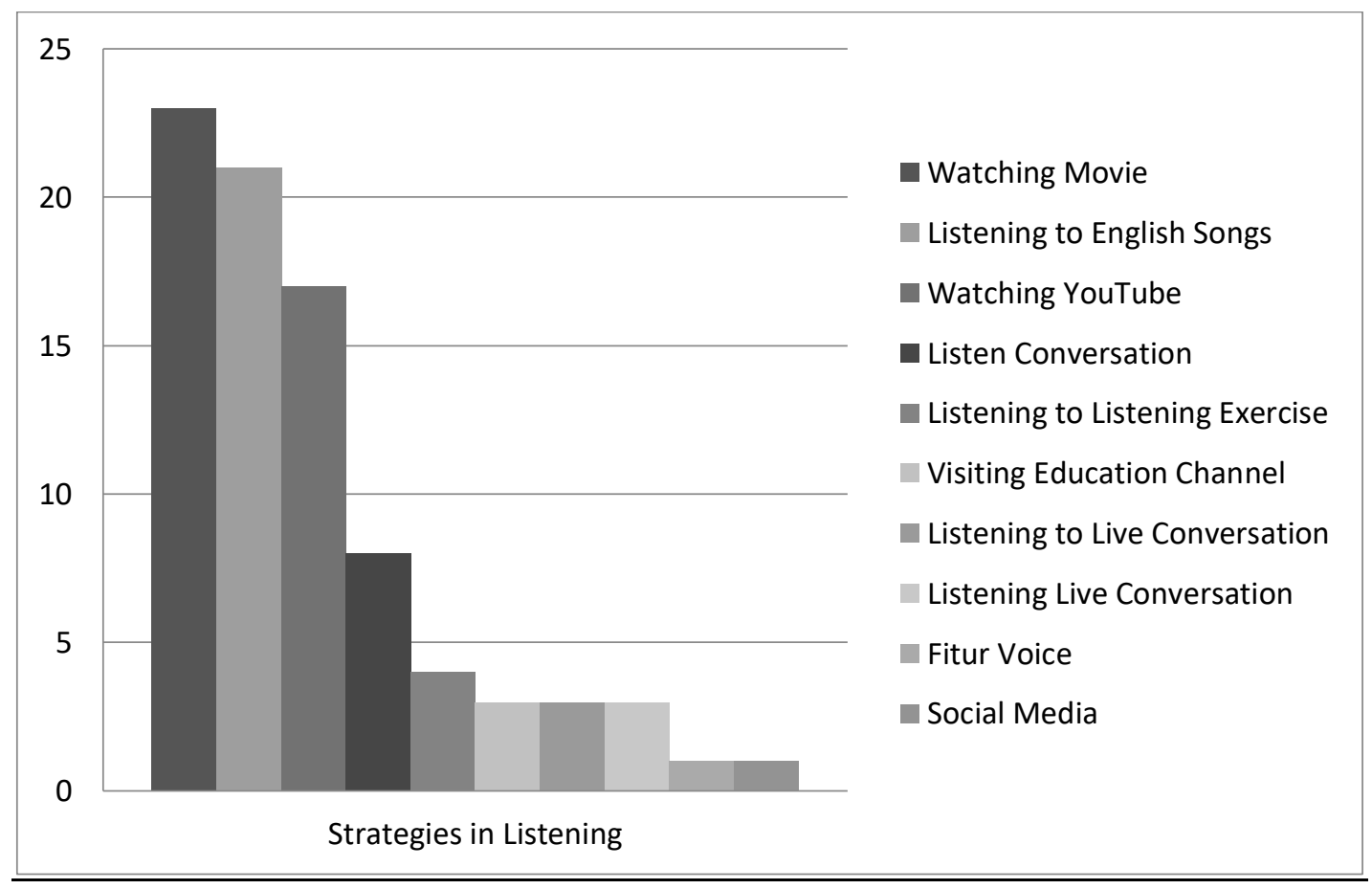

Figure 1. Strategies in Improving Listening Skill 
From Figure 1, it can be seen that there are 4 types of strategies that are most dominantly carried out by good language learners in improving their listening skills, including watching western films 57.5\%, listening to English songs 52.5\%, watching YouTube 42.5\%, and listening to English text conversations via the internet/web 20\%. The rest is through listening exercises, listening directly to conversations of English-speaking people, social media and so on. Of the 40 respondents, 23 people watch western films as a strategy to improve their listening skills, only 1 (one) person uses social media.

\section{Time Duration in Improving Listening Skills}

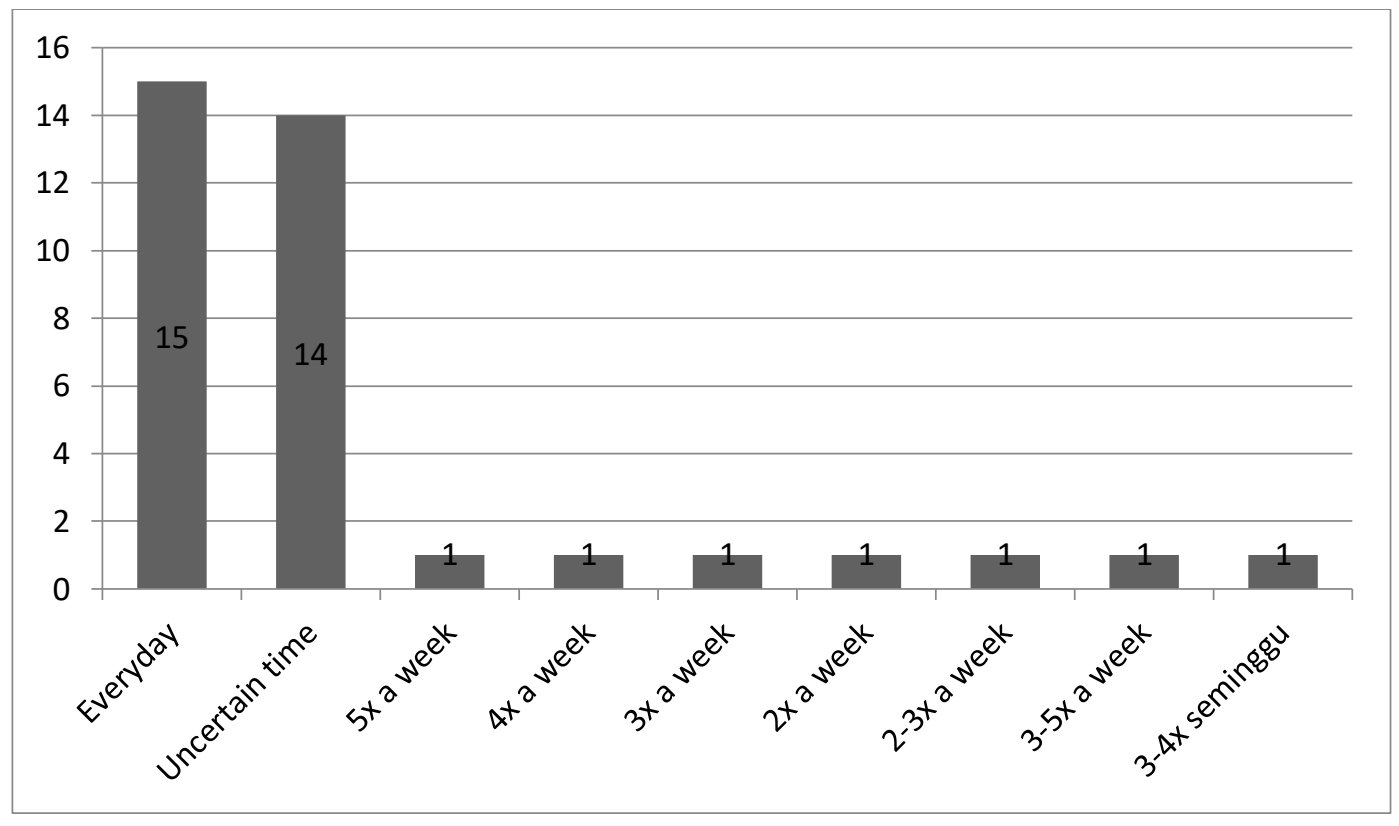

Figure 2. Duration of Improving Listening Skill

Based on Figure 4.3, it can be seen that how long the duration of time used by good language learners in learning to listen in a week. There are 15 people $(37.5 \%)$ who set aside time to study listening every day, 14 students do not have certain hours of study in a week. The rest are students who 5x a week, $4 \mathrm{x}$ a week $3 \mathrm{x}$ a week and $2 \mathrm{x}$ a week take the time to learn these listening skills.

\section{B. Learning strategies used by good language learners in improving their English speaking skills}

\section{Types of Strategies in Improving Speaking Skill}

Based on the results of data collection and analysis that has been carried out on good language learners in several different classes and different study programs, it was found that several strategies were used by them in improving their ability in speaking English skills. 


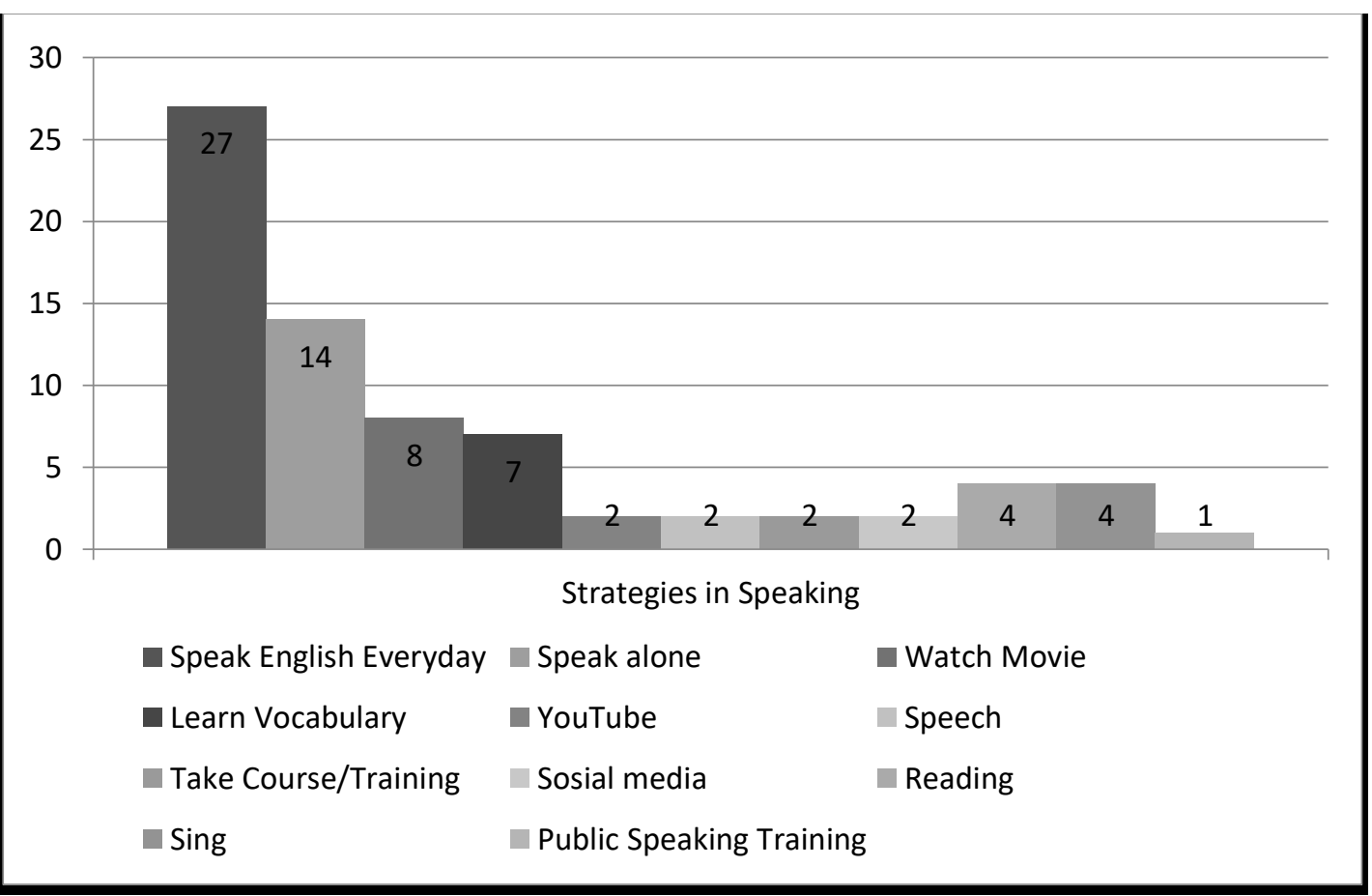

Figure 3. Strategies in Improving Speaking Skill

From Figure 3, it can be seen that some of the most dominant strategies carried out by good language learners in improving their speaking skills include 27 students who speak English everyday with friends or family (67.5\%), 14 students speak alone (35\%), 8 students watch western films (20\%) and 7 students learn vocabulary (17.5\%). The rest via YouTube, speech exercises, courses / tutoring, social media, reading, singing western songs and Public Speaking Training.

\section{Time Duration in Improving Speaking Skill}

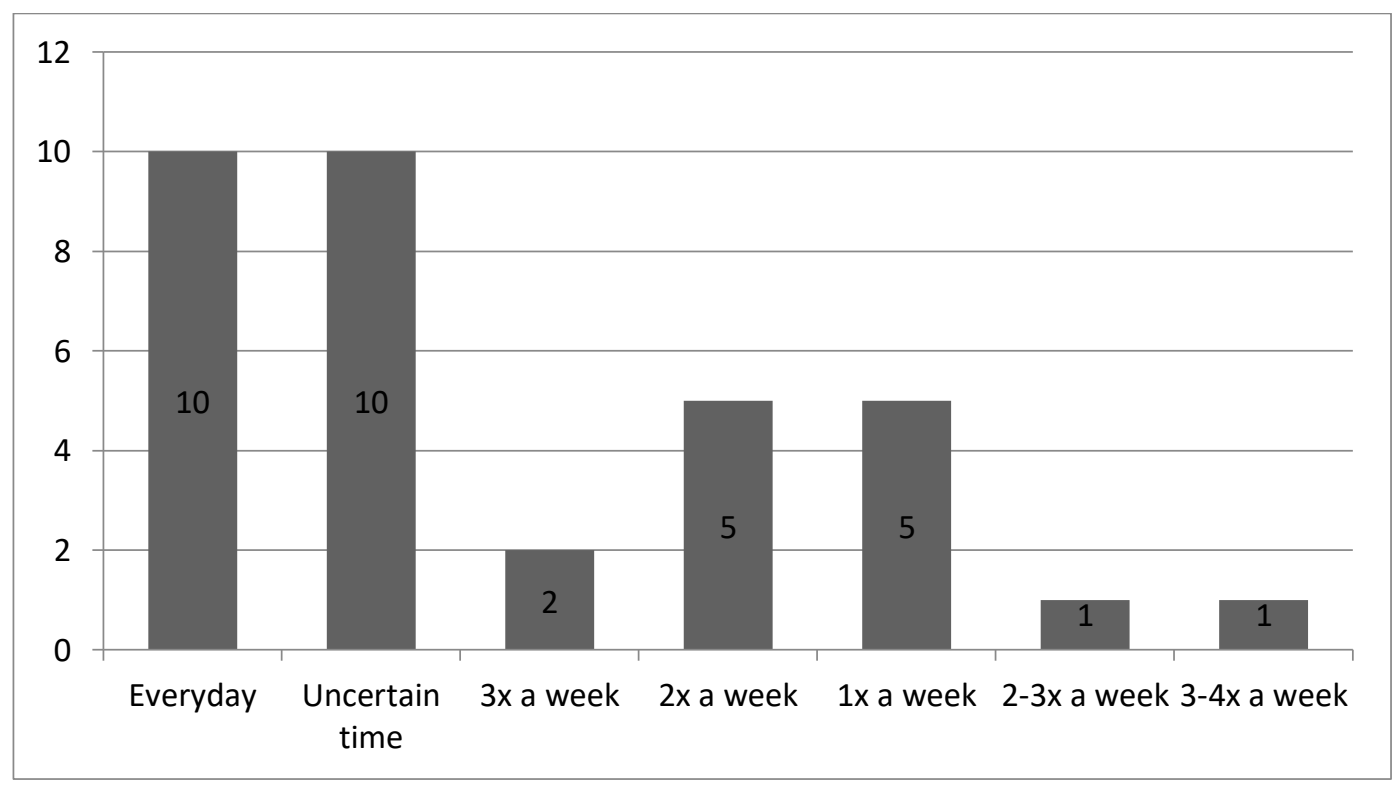

Figure 4. Duration in Improving Speaking Skill 
Based on Figure 4, it can be seen that how long the duration of time used by good language learners in learning to speak in a week. There are 10 people each $(25 \%)$ who set aside almost equal time to learn to speak every day as uncertain. The rest are students who spend $3 \mathrm{x}$ a week, $2 \mathrm{x}$ a week and only once a week learning these listening skills.

\section{Learning strategies used by good language learners in improving reading skill in English}

Based on the results of data collection and analysis that has been carried out on good language learners in several different classes and different study programs, it was found that several strategies were used by them in improving their abilities in reading English skills.

\section{Types of Strategies in Improving Reading Skill}

From Figure 5, it can be seen that some of the most dominant strategies performed by good language learners in improving their reading skills including reading books / articles in English as many as 27 people (67.5\%); 16 people (40\%) read novels / comics / other literary works in English; There are 5 people who improve their reading skills by looking for the meaning of difficult words found $(12.5 \%)$ and there are 3 students who read the Reading Section of the TOEFL test (7.5\%). The rest is through watching western films, social media, noting new vocabulary, doing exercises, through YouTube, through dictionaries, making summaries and getting used to using English in the cell phone menu.

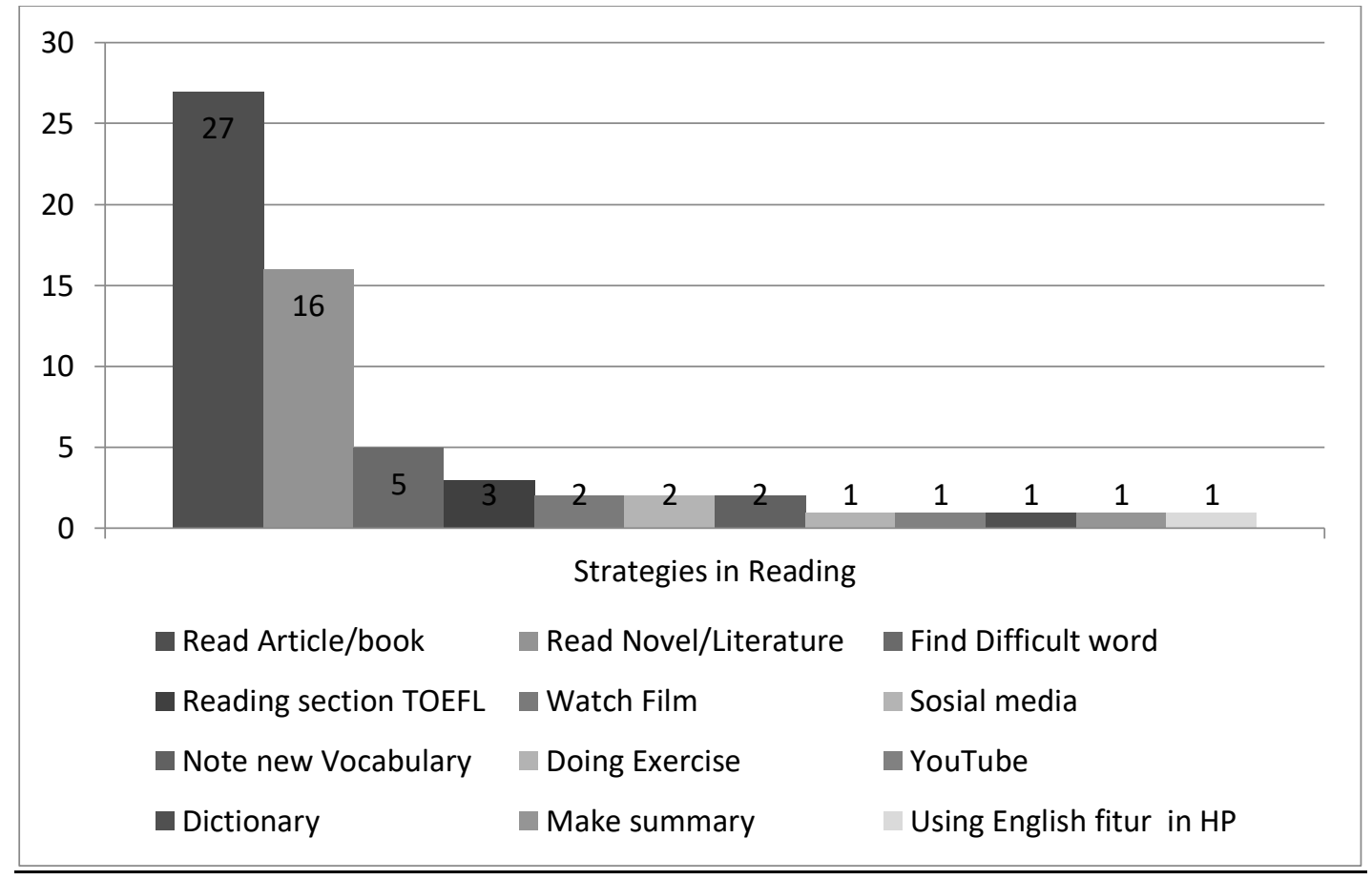

Figure 5. Strategies in Improving Reading Skill 


\section{Time Duration in improving Reading Skill}

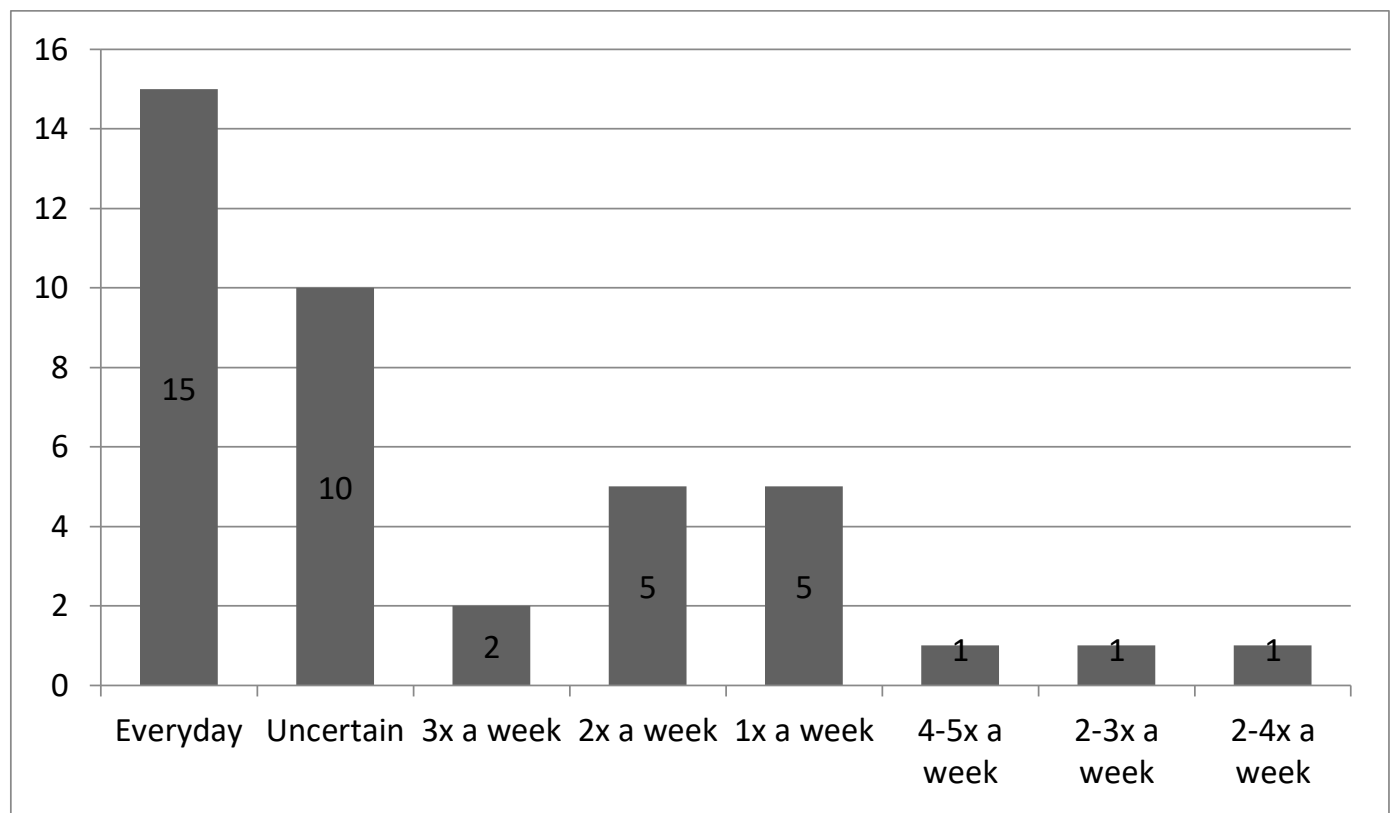

Figure 6. Duration in Improving Reading Skills

Based on Figure 6, it can be seen that how long the duration of time is used by good language learners in learning to read in a week. There are 15 people (37.5\%) who set aside time to study listening almost every day, while 10 people (25\%) do not have certain hours of study a week. The rest are students who are $3 \mathrm{x}$ a week, $2 \mathrm{x}$ a week once a week and so on.

\section{Learning strategies used by good language learners in improving their English writing skill}

Based on the results of data collection and analysis that has been carried out on good language learners in several different classes and different study programs, it was found that several strategies were used by them in improving their skills in English writing skills.

Types of Strategies in Improving Writing Skill 


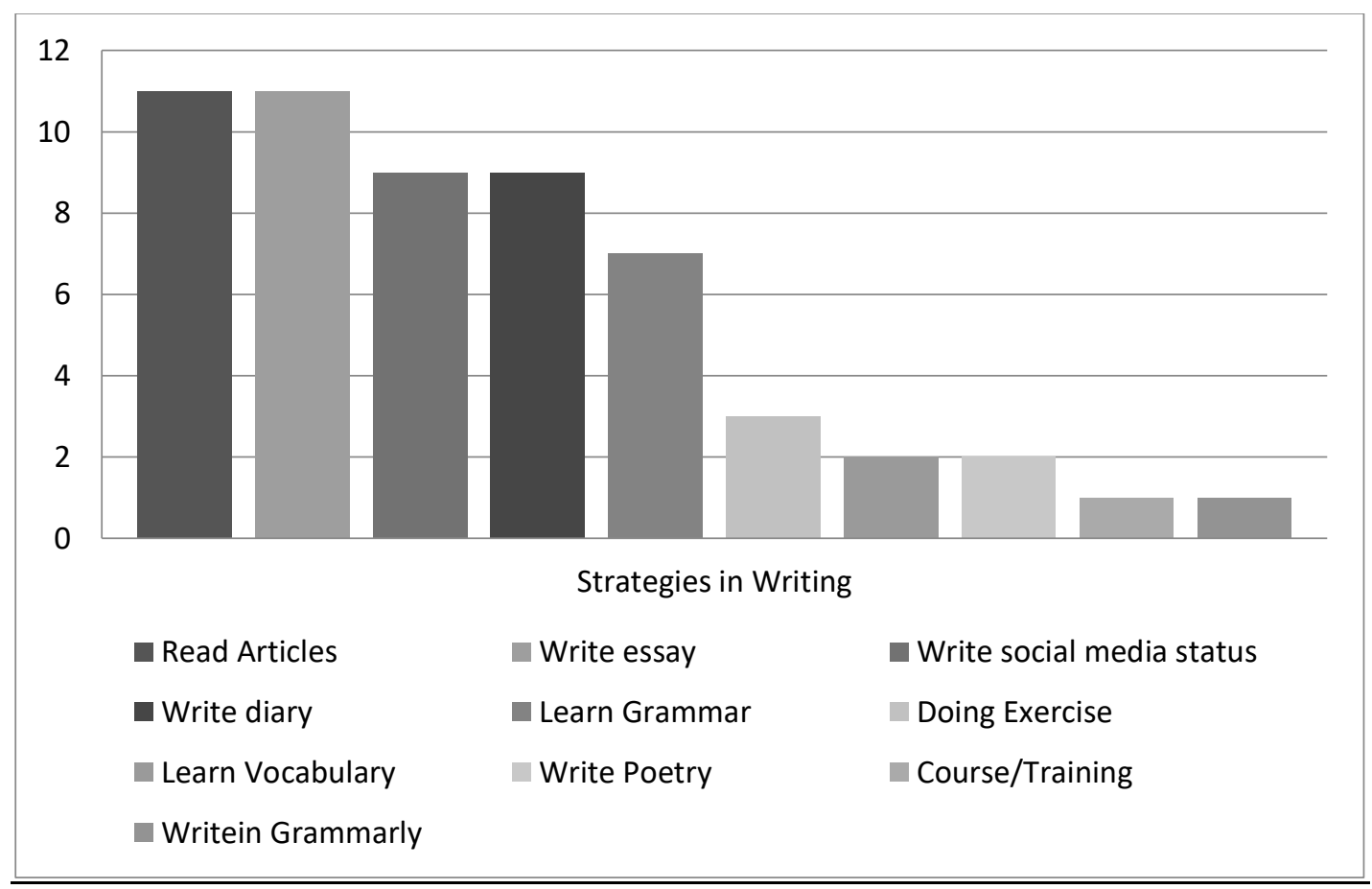

Figure 7. Strategies in Improving Writing Skill

From Figure 7, it can be seen that some of the most dominant strategies performed by good language learners in improving their writing skills include reading articles and writing essays by 11 students (27.5\%) respectively; there were 9 people writing their social media status and writing diaries in English (22.5\%); and there are 7 students who learn grammar to improve their writing skills (17.5\%). The rest is through doing exercises, learning vocabulary, writing poetry, courses / guidance and through writing with the Grammarly application.

\section{Time Duration in improving Writing Skill}

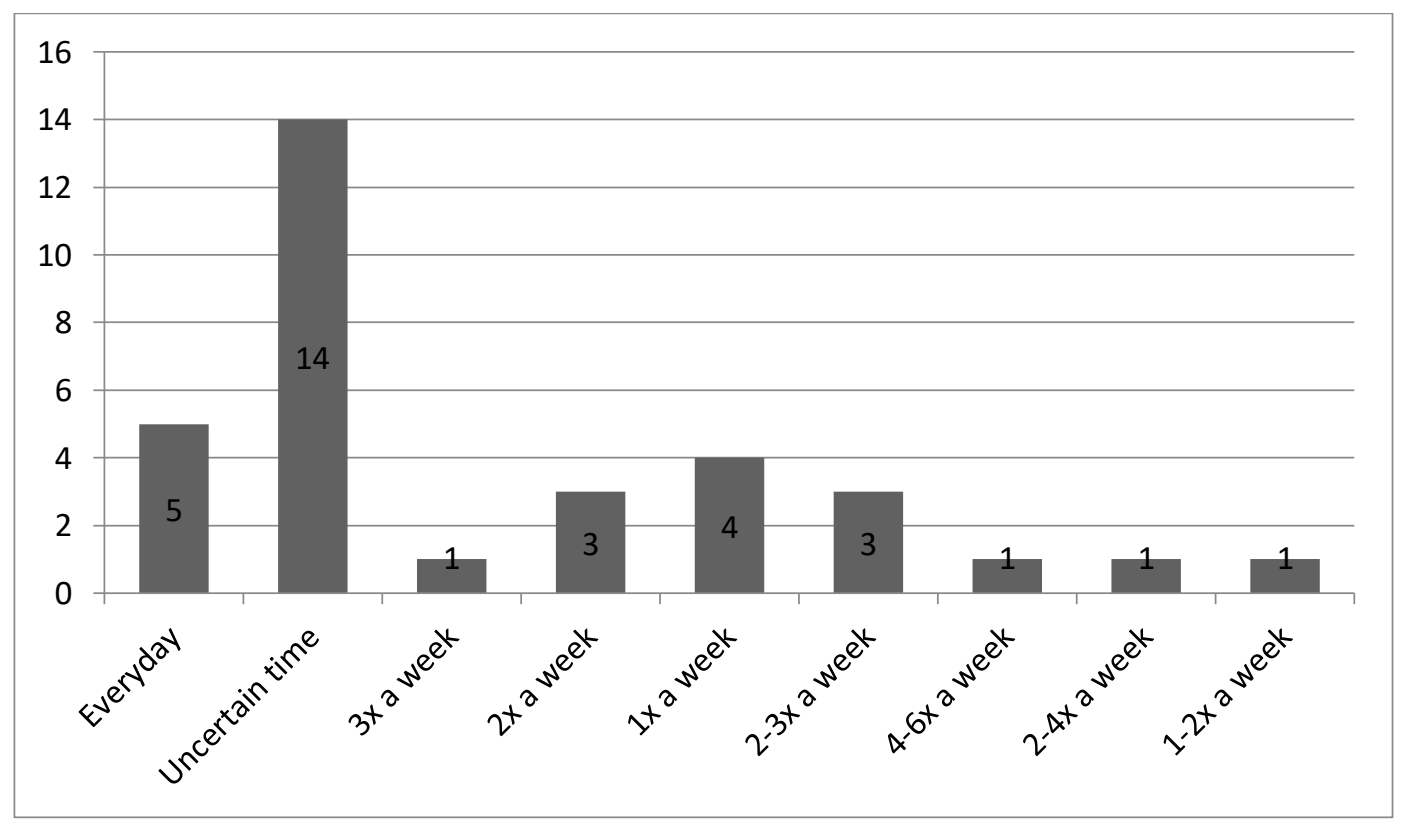


Figure 8. Duration in Improving Writing Skill

From Figure 8, it can be seen that how long the duration of time used by good language learners in learning to write in a week. There are 14 people $(35 \%)$ who set aside time to learn to write every day and 5 students who do not have fixed hours of study a week. The rest are students who take $3 \mathrm{x}$ a week, $2 \mathrm{x}$ a week once a week, take the time to learn these listening skills.

\section{Discussion}

Learning strategies carried out by outstanding millennial students in improving their language skills currently use electronic media or e-learning media. They take advantage of technological developments that exist today. E-learning can provide motivation and encourage students to learn language skills comprising listening, speaking, reading and writing English skills (Sakkir, 2016). The most dominant strategies carried out by good language learners in improving their listening ability include watching western movies, listening to western songs, watching via YouTube, and listening to English text conversations via the internet/ web. The most dominant strategies carried out by good language learners in improving their speaking skills include 27 students who spoke daily English with their friends or family, 14 people speak to themselves, 8 students watch western films, and 7 students learn vocabulary. The most dominant strategies performed by high achieving students in improving their reading skills include reading books/articles in English; reading novels, comics, other literary works in English; looking for the meaning of difficult words encountered and reading the Reading Section of the TOEFL test. Meanwhile, the most dominant strategies performed by good language learners in improving their writing skills included reading articles and writing essays by 11 students; there are 9 people writing status and writing diaries in English in their social media; and there are 7 students studying grammar to improve their writing skills.

In relation to Krashen's hypothesis, good language learners use more subconscious learning by watching western movies, listening to western songs, watching via YouTube, and listening to English text conversations via the internet/ web, speaking daily English with their friends or family; reading books/ articles in English; and reading novels/ comics/ other literary works in English. Several good language learners use formal learning by looking for the meaning of difficult words encountered and reading; Reading Section of the TOEFL test; and studying grammar to improve their writing skills. The findings support Krashen's hypothesis that there are two ways in improving language skills: conscious learning versus subconscious learning or learning versus acquisition. The findings also are in line with the emphasis of language acquisition over language learning.

The duration of time used by these good-performing students in improving their abilities also varies, some are learning certain skills every day, some are uncertain. In a week they spend at least 1 time and at most 5 times a week in learning a language skill.

\section{CONCLUSION}

\section{A. Conclusion}

Language learning strategies used by good language learners in improving their English listening skills include 6 strategies: watching western films, listening to western songs, watching YouTube videos, listening to English text conversations via the internet/web, doing listening exercises, listening directly to conversations of English-speaking people. Language learning strategies used by good language learners in improving their English speaking skills include 4 strategies: 
speaking English everyday with friends or family, speaking alone, watching western films, and learning vocabulary. Language learning strategies used by good language learners in improving their English reading skills include reading books/articles in English; reading novels/comics/other literary works in English; looking for the meaning of difficult words; reading the Reading Section of the TOEFL; watching western films, social media, noting new vocabulary, doing exercises, through YouTube, through dictionaries; and making summaries and getting used to using English in the cell phone menu. Language learning strategies used by good language learners in improving their English writing skills include 10 strategies: reading articles and writing essays; writing their social media status and writing diaries in English; learning grammar; through doing writing exercises, learning vocabulary, writing poetry, joining courses; and writing with the Grammarly application.

\section{B. Suggestions}

The suggestions regarding the results of this study are as follows: First, to the Makassar State University to continue to provide facilities and a forum for the empowerment of UNM human resources, especially lecturers and students through continuous research programs so that the level of analysis and awareness of learning and teaching problems is better. Second, English teachers and learners should always see the condition of students in the classroom in order to guide students to apply the best strategies in developing productive and receptive language skills, namely listening, speaking, reading and writing. Third, researchers in the field of teaching and learning English, especially in the field of teaching methods of language skills, can use the results of this study as a basis or reference for exploring language learning strategies used to develop students' English skills. And the forth, research results can be developed as part of the subject matter of Learning and Teaching, especially for the English Language Education Study Program.

\section{REFERENCES}

Atmowardoyo, Haryanto, 2018. "Research methods in TEFL studies: descriptive research, case study, error analysis, and R\&D," Journal of Language Teaching and Research, v. 9, n. 1, pp. 197-204, 2018.

Atmowardoyo, H., Weda, S., \& Sakkir, G. (2020). Information Technology used by Millennial Good English Language Learners in an Indonesian University to Improve their English Skills. Solid State Technology, 63(5), 9532-9547.

Bell, A. (1995). Language and the media.In Annual Review of Applied Linguistics 15, 23-41. Cambridge: Cambridge University Press.Brown,

Griffith, Carol (ed.), 2008. Lessons from Good Language Learners, Cambridge: Cambridge University Press.

Haryanto (1998). Motivasi dan Strategi Belajar pada Pembelajar Bahasa Inggris yang Berhasil di SMA, Disertasi S3, Jakarta: IKIP Jakarta.

Krashen, S. (1982). Principles and Practice in Second Language Acquisition. Oxford: Pergamon Press.

Malik, Agung Rinaldy \& Asnur, Muhammad Nur Ashar (2018). Using Social Media As A Learning Media Of Foreign Language Students In Higher Education, BAHTERA: Jurnal Pendidikan Bahasa dan Sastra, Volume 18 Issue 2 July 2019

Naiman Neil, Maria Fohlich, H.H. Stern \& Angie Todesco (1978). The Good Language Learner, Research in Education Series 7, Toronto: Ontario Institute for Studies in Education. 
Reiss, Ann (1985). "The Good Language Learner: Another Look." Canadian Modern Language Review 41: $511-23$.

Rubin, Joan, (1975). "What the 'Good Language Learner Can Teach Us.” TESOL Quarterly 9, pp: $41-51$.

Rubin, Joan, (1981). "Study of Cognitive Processes in Second Language Learning", Applied Linguistics Vol. 11 No. 2, pp. 124-125.

Sadtono, E., (1986). "Wanted: Good Language Learners", TEFLIN Journal Vol. VIII No. 1.

Sakkir, G., Rahman, Q., \& Salija, K. (2016). Students' Perception on Social Media in Writing Class at STKIP Muhammadiyah Rappang, Indonesia. International Journal of English Linguistics, 6(3), 170-175.

Sakkir, G., Dollah, S., \& Ahmad, J. (2020). Students' Perceptions toward Using YouTube in EFL Classrooms. Journal of Applied Science, Engineering, Technology, and Education, 2(1), $1-10$.

Sakkir, G., Dollah, S., Arsyad, S., \& Ahmad, J. (2021). Need Analysis for Developing Writing Skill Materials Using Facebook for English Undergraduate Students. International Journal of Language Education, 5(1), 542-551.

Stern, H.H. (1983). .Fundamental Concepts of Language Teaching. Oxford: Oxford University Press.

Stevick, Earl W. (1989). Success with Foreign Languages. Englewood Cliffs: Prentice-Hall. 


\section{Appendix: Research Instruments}

\section{Good Language Learners' Strategies in the Millennial Era: Positive Case Studies at Makassar State University}

Dear students, we are conducting research under the title as above. From our identification, you were selected as the respondents because you have the best GPA of $20 \%$.

The focus of the research is the Learning Strategy used by students with good achievements.

For the collection of the necessary data, we ask that you answer the questions given clearly and in detail.

Thank you for your participation. As a token of gratitude, we will send a pulse / quota of IDR 100,000 per respondent after the answer has been sent.

Research team

Prof. Dr. Haryanto Atmowardoyo, M.Pd.

Prof. Dr. Sukardi Weda, S.S., M.Hum., M.Pd., M.Si., M.M., M.Sos.I.

Dr. Geminastiti Sakkir, S.Pd., M.Pd.

* Required

Full name *

Your answer

Gender *

Man

Women

Age *

Your answer

Semester *

Your answer

Department *

English language education

English literature

Class *

Your answer

Last GPA *

Your answer

1. What did you do to improve your Listening Skill? Describe your answer clearly. * Your answer 
2. What did you do to improve your Speaking Skill? Describe your answer clearly. * Your answer

3. What did you do to improve your Reading Skill? Describe your answer clearly. * Your answer

4. What did you do to improve Writing Skill? Describe your answer clearly. * Your answer

5. What media do you use to increase Listening Skill? If you use a website, explain what the website is, why, how to use it, and what the results are. *

Your answer

6. What media do you use to improve your Speaking Skill? If you use a website, explain what the website is, why, how to use it, and what the results are. *

Your answer

7. What media do you use to improve your Reading Skill? If you use a website, explain what the website is, why, how to use it, and what the results are. *

Your answer

8. What media do you use to improve Writing Skill? If you use a website, explain what the website is, why, how to use it, and what the results are.*

Your answer

9. Approximately how many times per week do you learn to improve your Listening Skill? Also explain the duration of each of your study activities. *

Your answer

10. Approximately how many times per week do you study to improve your Speaking Skill? Also Your answer explain the duration of each of your study activities. *

11. Approximately how many times per week do you study to improve your Reading Skill? Also Your answer explain the duration of each of your study activities. *

12. Approximately how many times per week do you study to improve your Writing Skill? Also explain the duration of each of your study activities. *

Your answer

This question is mandatory 